\title{
Critical Role for Very-Long Chain Sphingolipids in Invariant Natural Killer T Cell Development and Homeostasis
}

OPEN ACCESS

Edited by:

Jin S. Im,

University of Texas MD Anderson Cancer Center, United States

Reviewed by:

Tonya J. Webb,

University of Maryland,

Baltimore, United States

Stephanie Dougan,

Dana-Farber Cancer Institute,

United States

Xiaodong Zhao,

Chongqing Medical

University, China

*Correspondence:

Yael Pewzner-Jung

yael.pewzner-jung@weizmann.ac.il

${ }^{+}$Present address:

Natalia S. Ferreira,

Institute of Pharmacology and

Toxicology, University of Zurich-

Vetsuisse, Zurich, Switzerland

Specialty section:

This article was submitted to Antigen Presenting

Cell Biology,

a section of the journal

Frontiers in Immunology

Received: 28 July 2017 Accepted: 09 October 2017 Published: 01 November 2017

Citation:

Saroha A, Pewzner-Jung $Y$, Ferreira NS, Sharma P, Jouan $Y$, Kelly SL, Feldmesser E, Merrill AH Jr., Trottein F, Paget $C$, Lang KS and Futerman AH (2017) Critical Role for Very-Long Chain Sphingolipids in

Invariant Natural Killer T Cell Development and Homeostasis.

Front. Immunol. 8:1386. doi: 10.3389/fimmu.2017.01386

\begin{abstract}
Ashish Saroha ${ }^{1}$, Yael Pewzner-Jung ${ }^{1 *}$, Natalia S. Ferreira ${ }^{1 \dagger}$, Piyush Sharma ${ }^{2}$, Youenn Jouan ${ }^{3}$, Samuel L. Kelly ${ }^{4}$, Ester Feldmesser ${ }^{5}$, Alfred H. Merrill Jr., François Trottein ${ }^{6}$, Christophe Paget ${ }^{3,6}$, Karl S. Lang ${ }^{2}$ and Anthony H. Futerman ${ }^{1}$

${ }^{1}$ Department of Biomolecular Sciences, Weizmann Institute of Science, Rehovot, Israel, ${ }^{2}$ Medical Faculty, Institute of Immunology, University Duisburg-Essen, Essen, Germany, ${ }^{3}$ INSERM U1100, Centre d'Etude des Pathologies Respiratoires, Faculté de Médecine, Tours, France, ${ }^{4}$ School of Biology and Petit Institute for Bioengineering and Bioscience, Georgia Institute of Technology, Atlanta, GA, United States, ${ }^{5}$ Life Science Core Facilities, Weizmann Institute of Science, Rehovot, Israel, ${ }^{6}$ Centre d'Infection et d'Immunité de Lille, INSERM U1019, CNRS UMR 8204, University of Lille, CHU Lille- Institut Pasteur de Lille, Lille, France
\end{abstract}

The role of sphingolipids (SLS) in the immune system has come under increasing scrutiny recently due to the emerging contributions that these important membrane components play in regulating a variety of immunological processes. The acyl chain length of SLs appears particularly critical in determining SL function. Here, we show a role for very-long acyl chain SLs (VLC-SLs) in invariant natural killer T (iNKT) cell maturation in the thymus and homeostasis in the liver. Ceramide synthase 2-null mice, which lack VLC-SLS, were susceptible to a hepatotropic strain of lymphocytic choriomeningitis virus, which is due to a reduction in the number of iNKT cells. Bone marrow chimera experiments indicated that hematopoietic-derived VLC-SLs are essential for maturation of NKT cells in the thymus, whereas parenchymal-derived VLC-SLs are crucial for INKT cell survival and maintenance in the liver. Our findings suggest a critical role for VLC-SL in iNKT cell physiology.

Keywords: very-long chain ceramides, glycosphingolipids, invariant natural killer T cells, ceramide synthase 2, lymphocytic choriomeningitis virus, liver, thymus

\section{INTRODUCTION}

Natural killer T (NKT) cells are a subset of T lymphocytes that act at the interface between the innate and adaptive immune systems (1). A subset of NKT cells, termed invariant NKT (iNKT) cells, is found at low levels ( $<1 \%$ of hematopoietic cells) in many organs but is highly enriched in the liver, where it represents up to $30 \%$ of resident T lymphocytes (2). $i$ NKT cells express a restricted $\mathrm{T}$ cell receptor (TCR) repertoire composed of an invariant TCR $\alpha$ chain $(\mathrm{V} \alpha 14-\mathrm{J} \alpha 18$ in mice and $\mathrm{V} \alpha 24-\mathrm{J} \alpha 18$ in humans) paired with a limited number of $\beta$ chains (V $\beta 8.2, \mathrm{~V} \beta 7$, or $\mathrm{V} \beta 2$ in mice and V $\beta 11$ in humans). $i$ NKT TCRs recognize CD1d-restricted glycolipid ligands, among them a glycosphingolipid (GSL), $\alpha$-galactosylceramide ( $\alpha$-GalCer), which was originally isolated from a marine sea sponge. Reactivity to $\alpha$-GalCer is used to define $i \mathrm{NKT}$ cells and distinguishes them from other NKT subsets (3). Most mammalian GSLs exist as $\beta$ anomers although there is some evidence that mammalian $\alpha$-linked glycosylceramides are also found $(4,5)$. 
Glycosphingolipids consist of a ceramide backbone to which various glycans are added at the $\mathrm{C} 1$ position. Ceramide itself is comprised of a sphingoid long chain base to which a fatty acid is $\mathrm{N}$-acylated, with each of the six mammalian ceramide synthases catalyzing the addition of fatty acids with different acyl chain lengths $(6,7)$. The acyl chain length appears particularly critical in determining SL function (8). Specifically, very-long acyl chain (VLC) GSLs have been studied extensively in immune cell regulation (9-13), and it was suggested that VLC-GSLs, such as C24:1-glucosylceramide (GlcCer) might serve as self-antigens required for thymic $i$ NKT cell maturation $(4,14,15)$.

In the current study, we take advantage of a mouse which is unable to generate VLC-sphingolipids (SLs) [with a C22-C24 acyl chain length (16)] to study the impact on $i$ NKT cell homeostasis. Ceramide synthase 2 (CerS2)-null mice display liver (17-19), brain (20), lung $(21,22)$, and adrenal gland pathologies (23). These disorders are caused by a variety of factors including increased cellular turnover of hepatocytes (17), dysfunction of specific membrane proteins and receptors $(18,24-26)$, impaired mitochondrial complex IV activity (19), demyelination (20), chronic lung inflammation (21), and oxidative stress (23), which can be caused either by changes in levels of specific SLs or by changes in the biophysical properties of membranes (27).

We demonstrate that CerS2-null mice display a significant reduction of $i \mathrm{NKT}$ cells in the thymus and liver, which render CerS2-null mice susceptible to infection with a hepatotropic strain of the lymphocytic choriomeningitis virus (LCMV-WE); susceptibility to infection is overcome upon adoptive transfer of wild-type (WT) $i$ NKT cells. Our data support the notion that VLC-GSLs act as endogenous self-ligands for $i$ NKT cell development in the thymus (4). Moreover, akin to other naïve lymphocytes which depend on low affinity self-ligand exposure for survival $(28,29), i \mathrm{NKT}$ cells require similar parenchymal survival signals in the liver.

\section{MATERIALS AND METHODS}

\section{Reagents and Antibodies}

The following antibodies were from Bio-Legend (San Diego, CA, USA): anti-CD16/32 FcyR (clone 93); Pacific blue anti-mouse CD45 (clone 30-F11); allophycocyanin (APC) anti-mouse CD45.1 (clone A20); APC or phycoerythrin (PE)/Dazzle 594 anti-mouse CD3 (clone 17 A2); PercpCy5.5 anti-mouse CD4 (clone GK1.5); fluorescein isothiocyanate anti-mouse CD8a (clone 53-6.7); Alexa Fluor 700 anti-mouse CD44 (clone 1M7); PE-Cy7 anti-mouse CD24 (clone M1/69); Pacific blue anti-mouse CD1d (clone 1B1); APC-Cy7 anti-mouse CD19 (clone 6D5); PE anti-mouse Ly6G (clone 1A8); Pacific blue anti-mouse Ly6C (clone HK1.4); APC-Cy7 anti-mouse CD11b (clone M1/70); PE-Dazzle anti-mouse CD11c (clone N418); PE anti-mouse B220 (clone RA3-6B2); and PercpCy5.5 anti-mouse PDCA1 (clone 927). An APC anti-mouse IFN $\gamma$ antibody (clone XMG1.2) and APC-streptavidin were from eBioscience, MA, USA. A biotin-anti-mouse-NK1.1 antibody (clone PK136) was from Bio-gems International Inc., CA, USA. PE anti-mouse F4/80 (clone Cl:A3-1) was from AbD Serotec, Oxford, UK, and
PE- or Alexa 488-anti-mouse CD1d-PBS57 tetramer (PBS-57 is a synthetic analog of $\alpha$-GalCer) was provided by the NIH tetramer core facility at Emory University, Atlanta, GA, USA. Rat antiLCMV serum was made in-house and the Cy3 donkey anti-rat antibody was from Jackson ImmunoResearch Laboratories Inc., PA, USA.

An IFN- $\alpha$ ELISA kit was from Thermo Fischer Scientific Inc., USA, anti-PE magnetic microbeads were from Miltenyi Biotec, Bergisch Gladbach, Germany, an RNeasy mini kit was from Qiagen (Venlo, Netherlands), a qScript ${ }^{\mathrm{TM}}$ C-DNA synthesis kit was from Quanta Biosciences Inc. (MA, USA), the Perfecta SYBR Green fastMix was from Quanta Biosciences Inc. (MA, USA), and a IL-2 ELISA kit was from R\&D systems (Minneapolis, MN, USA). $\alpha$-GalCer was produced as described (30). Brefeldin A was from Sigma-Aldrich (St. Louis, MO, USA).

\section{Mice}

Ceramide synthase 2 null and WT littermate control mice were generated by crossing C57BL/6 CerS2 ${ }^{+/-}$mice with $129 \mathrm{~S} 2 \mathrm{v} / \mathrm{Jae}$ CerS2 ${ }^{+/-}$mice (16). Mice were housed in a specific pathogenfree barrier facility at the Weizmann Institute of Science. Experimental procedures were performed in accordance with guidelines approved by the Institutional Animal Care and Use Committee.

\section{LCMV-WE Virus Infection}

LCMV-WE was propagated in baby hamster kidney 21 cells. The viral titer was determined by a plaque assay (31). Two million plaque-forming units (PFU) of LCMV-WE were injected intravenously through the retro-orbital plexus into CerS2-null mice. Mice were sacrificed 2 and 6 days later and their livers and spleens removed. The big lobe of the liver was fixed in optimal cutting temperature freezing medium and the rest of the liver frozen at $-80^{\circ} \mathrm{C}$. Liver sections $(5 \mu \mathrm{m})$ were cut using a cryostat (Leica Systems, Nussloch, Germany) and dried overnight at room temperature. Sections were used for anti-LCMV staining or stored at $-20^{\circ} \mathrm{C}$. Sections were fixed with acetone for $10 \mathrm{~min}$ and blocked with 10\% fetal bovine serum (FBS) for $1 \mathrm{~h}$. Sections were stained with rat anti-LCMV serum for $1 \mathrm{~h}$ followed by three washings with PBS. Sections were incubated with a Cy3conjugated donkey anti-rat antibody (1:700 in 1\% FBS) and counterstained with Hoechst 33342 (Molecular Probes, OR, USA) for $5 \mathrm{~min}$ and washed three times with PBS. Sections were mounted using Fluoromount G mounting medium (Southern Biotech, AL, USA). Slides were dried overnight and images were captured using a Nikon eclipse Ti-s inverted microscope. Images were processed using NIS elements 3.0 imaging software (Nikon Instruments Inc., NY, USA).

\section{In Vitro Restimulation of LCMV-Specific T Cells}

For intracellular cytokine staining, isolated liver cells were incubated with or without the LCMV-specific peptides, GP33 $(0.1 \mu \mathrm{M})$, or GP64 $(1 \mu \mathrm{M})$. After $1 \mathrm{~h}$, brefeldin A $(5 \mu \mathrm{g} / \mathrm{ml})$ was added to block cytokine secretion (32), followed by an additional $5 \mathrm{~h}$ incubation at $37^{\circ} \mathrm{C}$. After surface staining with anti-CD8 
or anti-CD4 antibodies, cells were fixed with $2 \%$ formalin and permeabilized with PBS containing 1\% fetal calf serum (FCS) and $0.1 \%$ saponin, and stained with an anti-IFN- $\gamma$ antibody for $30 \mathrm{~min}$ at $4^{\circ} \mathrm{C}(32)$.

\section{RNA-seq Processing and Analysis}

Liver was homogenized in $750 \mu \mathrm{l}$ Trizol reagent (Invitrogen) and vortexed after adding $150 \mu \mathrm{l}$ chloroform and incubated for $5 \mathrm{~min}$ at room temperature, followed by centrifugation for $15 \mathrm{~min}$ at $20,000 \mathrm{~g} .300 \mu \mathrm{l}$ from the upper phase was transferred to a new microtube and after the addition of $70 \%$ ethanol (1:1 vol), transferred to an RNeasy column (RNeasy mini kit, Qiagen). RNA was purified following DNase I digestion on the column according to manufacturer's instructions. For library preparation, $6.1 \mu \mathrm{l}$ of total RNA ( $5 \mathrm{ng} / \mu \mathrm{l}$ ) was used for the MARS-seq protocol (33). RNA-seq libraries were sequenced using Illumina NextSeq-500. For analysis, adapters and low quality bases were removed from the raw reads using cutadapt (34). The remaining reads were mapped to the Mus musculus genome (mm10) using STAR v2.4.2a (35) with the option alignEndsType EndToEnd. Only reads with unique mapping were considered for further analysis. Gene expression levels were calculated using htseq-count (36) with option intersection-strict and mm10 Refseq 3'UTR GTF annotations. Duplicate reads were filtered if they mapped to the same gene and had identical UMIs. Normalization and differential expression analysis was performed using the DESeq2 R-package (Bioconductor, https:// bioconductor.org/packages/release/bioc/html/DESeq2.html). Differentially expressed genes were defined as genes that had a significant adjusted $p$ value $(<0.05)$ and at least twofold change. Differentially expressed genes in at least one of the comparisons were clustered using the $k$-means algorithm (Partek ${ }^{\circledR}$ Genomics Suite software, Partek Inc., St. Louis, MO, USA) with Pearson's dissimilarity as the distance metric. The value of $k$ was evaluated by the Davies-Bouldin criterion for a range of possible values (1-20) and visual inspection of local minimums. Heatmaps were drawn with Partek.

\section{Quantitative Real-time PCR}

Total RNA was isolated using an RNeasy mini kit according to manufacturer's instructions. cDNA synthesis was performed using a QScript ${ }^{\mathrm{TM}} \mathrm{C}$-DNA synthesis kit and qPCR performed using the Perfecta SYBR Green fastMix and an ABI Prism 7000 Sequence Detection System (Applied Biosystems, Life Technologies). The sequence of real-time primers for LCMV-glycoprotein was, forward, 5'CGCACCGGGGATCCTAGGC 3', reverse, 5'ATACTCATGAGTGTATGGTC 3'. The following primers were purchased from Qiagen Inc., with catalog numbers indicated: GAPDH, QT01658692; MX1, QT01064231; IRF7, QT00245266; OAS1, QT01056048; ISG15, cat QT02274335; Bst2, QT01066184; and Usp18, QT00167671. The sequence of primers used for the validation of differentially expressed genes found in RNAseq analysis was: Orm2, forward, 5'TGGAAGCTCAGAACCCAGAAC 3', reverse 5' GCCGGTAATCAGGGTTTAGG 3'; Saa2, forward, 5' CTAGGAACACTGAAGATGCTCTC 3', reverse 5'TCTCCTC CTCAAGCAGTTACTA 3'; Saa3, forward 5'AGCCAAAGATG GGTCCAGTT 3', reverse, 5' TAGGCTCGCCACATGTCTCT
3'; Hpx, forward, 5' GGGAGAGTTGCCGAAGTTGA, reverse, 5'CCTCCACACAAACTCCCCTTT 3'; $H p$, forward, 5' TTCTAC AGACTACGGGCCGA 3', reverse, 5' CCCACACACTGCCTCA CATT 3'; Apcs, forward, 5'GCTACGTAGTCATCAGGCCC 3', reverse, 5'GACCTCTTACACATCGGCCA 3'.

\section{Flow Cytometry}

Approximately $10^{6}$ cells were blocked with an anti-CD16/32 Fc $\gamma$ R antibody for $10 \mathrm{~min}$ and subsequently stained with fluorescently labeled antibodies for $10 \mathrm{~min}$. Flow cytometry was performed on an LSR II flow cytometer (BD Biosciences, San Jose, CA, USA) and analyzed using Flow Jo V10 software (Flow Jo, LLC, Ashland, OR, USA).

\section{Hepatocytes and Mononuclear Cell (MNC) Isolation}

Hepatocytes were isolated as described (37). For isolation of MNCs, the supernatant obtained after separating hepatocytes was centrifuged at $300 \mathrm{~g}$ to pellet MNCs. Erythrocytes were lysed with ammonium chloride, potassium (ACK) buffer $(150 \mathrm{mM}$ $\mathrm{NH}_{4} \mathrm{Cl}, 10 \mathrm{mM} \mathrm{KHCO}, 0.1 \mathrm{mM}$ EDTA, $\mathrm{pH}$ 7.2), and dead cells separated on a $40 \%$ Percoll gradient by centrifugation $(30 \mathrm{~min}$, $300 \mathrm{~g}$ ). The pellet containing MNCs was resuspended in PBS containing 1\% BSA and cells counted using a hemocytometer.

Splenocytes and thymocytes were isolated after mechanical disruption in PBS containing 1\% BSA followed by filtration through a $70-\mu \mathrm{m}$ cell strainer. Splenocytes were incubated in ACK buffer for 2 min to lyse erythrocytes. Live cells were counted in a hemocytometer using trypan blue. Blood was withdrawn retro-orbitally using capillaries containing anti-coagulating agents. Erythrocytes were lysed using ACK lysis buffer for 2 min. The cells were washed, suspended in PBS, and counted in a hemocytometer.

\section{Generation of Bone Marrow (BM)-Derived Cells and In Vitro iNKT Cell Activation Assay}

Bone marrow-derived cells were cultured in Iscove's Modified Dulbecco's Medium supplemented with 10\% FCS with $1 \%$ (of total volume) of a supernatant from a granulocyte-macrophage colony-stimulating factor (GM-CSF)-expressing cell line (J558-GM-CSF) (38). Dendritic cells (DCs) were used on day 14 of culture. This protocol yielded $>90 \%$ cell purity as evaluated by FACS (DCs were identified by cell surface expression of $\left.\mathrm{CD} 11 \mathrm{c}^{+} \mathrm{MHC} \mathrm{II}\right)$. DCs $\left(1 \times 10^{5}\right.$ cells $\left./ \mathrm{ml}\right)$ were cocultured with $1 \times 10^{5}$ cells of a mouse type I NKT cell hybridoma (DN32.D3) in the presence of vehicle or various concentrations of $\alpha$-GalCer (10-100 ng/ml) in complete Roswell Park Memorial Institute media supplemented with 5\% FCS for $24 \mathrm{~h}$. Supernatants were collected and the IL-2 concentration measured by ELISA (R\&D systems, MN, USA).

\section{iNKT Cell Enrichment and Adoptive Transfer}

Invariant NKT cells from liver MNCs were enriched using antiPE microbeads (Miltenyi Biotec, Bergisch Gladbach, Germany). 
Briefly, MNCs from livers obtained from at least seven mice were isolated, pooled, and blocked with an anti-CD16/32 antibody for $10 \mathrm{~min}$ at $4^{\circ} \mathrm{C}$ in PBS containing 1\% BSA. Ten microliters each of a PE-conjugated CD1d-PBS57 tetramer were added per $10^{7}$ cells in $100 \mu$ of magnetic-activated cell sorting (MACS) buffer (PBS containing $0.5 \%$ BSA and $2 \mathrm{mM}$ EDTA) and incubated for $10 \mathrm{~min}$ in the dark at $4^{\circ} \mathrm{C}$. The cells were washed and resuspended in $80 \mu \mathrm{l}$ of PBS to which $20 \mu \mathrm{l}$ of anti-PE microbeads per $10^{7}$ cells were added and kept in the dark for $15 \mathrm{~min}$ at $4^{\circ} \mathrm{C}$. Cells were washed and resuspended in $500 \mu \mathrm{l}$ of MACS buffer. Cells were passed through a magnetic separation column followed by three washings to remove unbound cells. The magnetic labeled-bound cells were released from the column by removing the magnet and flushing the column with a syringe plunger. The purity of enriched $\mathrm{CD}^{+}$and CD1d/PBS-57 tetramer ${ }^{+}$cells was determined by flow cytometry. One million $i$ NKT cells were washed and resuspended in $200 \mu \mathrm{l}$ of PBS. Cells were injected i.v. through the retro-orbital plexus into CerS2-null mice. As a control, an equal amount of PBS was injected into CerS2-null mice.

\section{Generation of BM Chimeras}

C57BL/6 CD45.1+ WT mice were crossed with WT 129S4/ SvJae CD $45.2^{+}$mice to generate WT C57BL/6;129S4/SvJae F1 mice, which carry both CD45.1 and CD45.2. BM was collected from the tibia and femurs of C57BL/6 × 129S4/SvJae F1 CerS2null mice (expressing only CD45.2 ${ }^{+}$) and WT mice and cells (excluding erythrocytes) were counted using a hemocytometer. CerS2-null mice and WT recipients were irradiated with 1,000 cGy and given antibiotics (ciprofloxacin, 1.0\% vol/vol) in their drinking water for 2 weeks. The next day, mice were injected i.v. with $3 \times 10^{6} \mathrm{BM}$ cells. Chimeras were generated by injecting $\mathrm{BM}$ cells from WT mice to CerS2-null mice (WT $>\mathrm{KO}$ ) and CerS2-null mice to WT mice $(\mathrm{KO}>\mathrm{WT})$ along with $\mathrm{WT}>\mathrm{WT}$ and $\mathrm{KO}>\mathrm{KO}$ controls. Chimeras were analyzed for the presence of donor WT $\left(\mathrm{CD} 45.1^{+} \mathrm{CD} 45.2^{+}\right)$or CerS2 null $\left(\mathrm{CD} 45.2^{+}\right) i \mathrm{NKT}$ cells in the thymus and liver 8-10 weeks after $\mathrm{BM}$ transfer.

\section{SL Analysis}

Sphingolipid levels were analyzed by liquid chromatographyelectrospray ionization-tandem mass spectrometry (LC ESI-MS/ MS) using an ABI4000 quadrupole-linear ion trap mass spectrometer as described previously (39).

\section{Statistical Analysis}

Data are expressed as means \pm SEM. An unpaired student's $t$-test was used to determine statistically significant differences between groups; ${ }^{\star} p<0.05,{ }^{* *} p \leq 0.01$, and ${ }^{* *} p \leq 0.001$.

\section{RESULTS}

\section{CerS2-Null Mice Are Susceptible to LCMV-WE Infection}

To determine the role of CerS2 in host defense against pathogens, we infected CerS2-null mice with a hepatotropic strain of LCMV, which activates pathways of both innate and adaptive immunity and causes acute hepatitis in mice (40). Two days postinfection (DPI) with $2 \times 10^{6} \mathrm{PFU}$ of LCMV, increased levels of the virus were detected in the liver of CerS2-null mice compared to WT mice as ascertained by immunofluorescence (Figure 1A) and by viral titers (Figure 1B). No differences in infection were observed 6 DPI in the liver, and no changes in infection were seen in the spleen at either time point (Figure 1B). Cultured hepatocytes from WT and CerS2-null mice did not display differences in infection excluding the possibility that altered LCMV internalization or proliferative capacity in hepatocytes is the primary cause for the enhanced susceptibility of CerS2-null mice to hepatic LCMV infection (Figure S1A in Supplementary Material).

IFN $\alpha$ is critical for defense against virus infection (41) but, unexpectedly, levels of IFN $\alpha$ were higher in CerS2-null liver 2 DPI compared to WT mice (Figure 1C) and downstream components of IFNAR1 signaling pathway were unaltered (Figure 1D). Likewise, levels of plasmacytoid dendritic cells (pDCs), the major source of IFN $\alpha$ after viral infection (42), were increased in CerS2 null liver (Figure S1B in Supplementary Material). Levels of monocytes were unaltered (Figure S1C in Supplementary Material), whereas neutrophils (Figure S1D in Supplementary Material) and $\mathrm{CD}^{+} \mathrm{T}$ cells (Figure 1E) were increased in CerS2-null mouse liver prior to infection, probably due to increased hepatocyte turnover (17). The percent of $\mathrm{CD}^{+}{ }^{+} \mathrm{T}$ cells was lower in CerS2-null mouse liver before and after viral infection (Figure 1F). However, LCMV-specific CD8 ${ }^{+}$ $\mathrm{T}$ cells were unaltered (Figure 1G), while LCMV-specific CD $4^{+}$ $\mathrm{T}$ cells (Figure 1H) were increased in CerS2 null mouse liver 6 DPI, indicating that impairment of conventional $\mathrm{T}$ cell responses cannot explain the enhanced susceptibility. In conclusion, the susceptibility of CerS2 null liver to LCMV infection after 2 days cannot be accounted for by increased viral internalization into hepatocytes, to a type I IFN response or to virus-specific T cell responses.

\section{Lack of iNKT Cells Renders CerS2-Null Mice Susceptible to LCMV Infection}

Since the number of $\mathrm{CD} 4^{+} \mathrm{T}$ cells was decreased in CerS2 null mouse liver (Figure 1F), we examined levels of $i$ NKT cells, which form a major fraction of hepatic $\mathrm{CD} 4^{+} \mathrm{T}$ cells and are involved in protection against pathogens, including viral infection (43-45). Flow cytometry revealed a striking decrease in the percent and number of $i$ NKT cells in CerS2 null liver (Figures 2A,B). To determine if the reduction in the number of $i$ NKT cells is responsible for viral infection, mice were engrafted with WT $i$ NKT cells 1 day prior to LCMV infection. Adoptive transfer of an enriched $i$ NKT fraction abolished the enhanced susceptibility of CerS2-null mice to LCMV infection (Figures 2C,D), while the $i \mathrm{NKT}$-depleted fraction (containing high levels of conventional T cells and low levels of $i$ NKT cells) did not (Figure S3 in Supplementary Material).

To further delineate the role of $i \mathrm{NKT}$ cells in hepatic LCMV infection, we performed 3'UTR digital gene expression RNA-seq (Data Sheet S1 in Supplementary Material) and compared genes that were differentially expressed between 
A
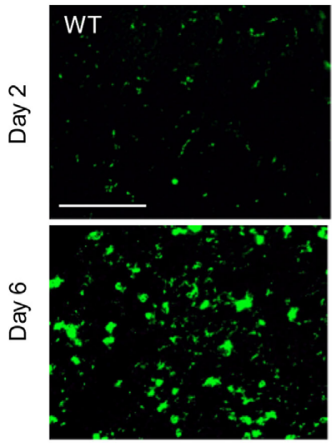

C

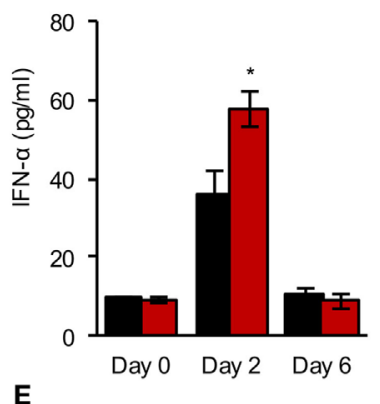

E

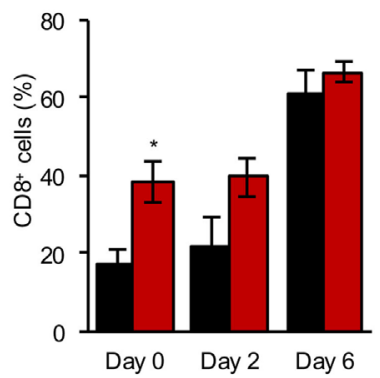

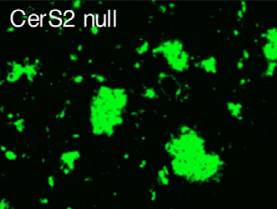

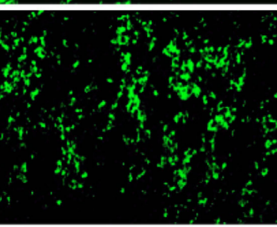

D

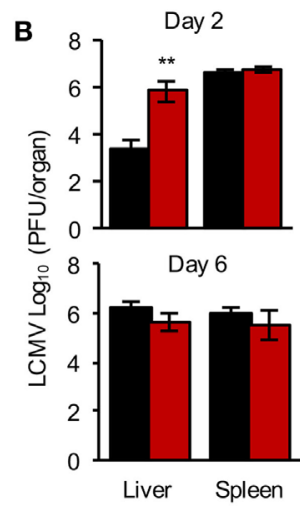

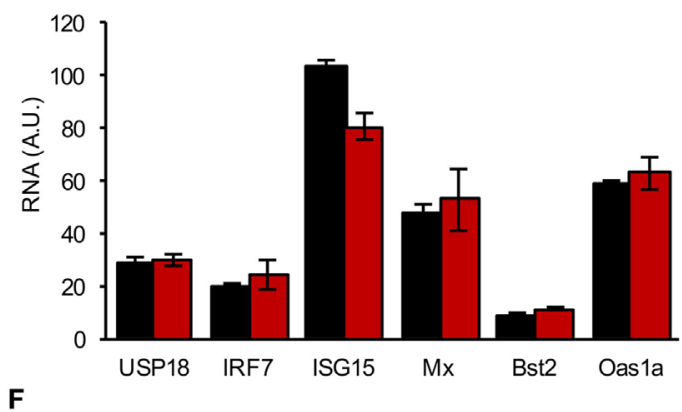

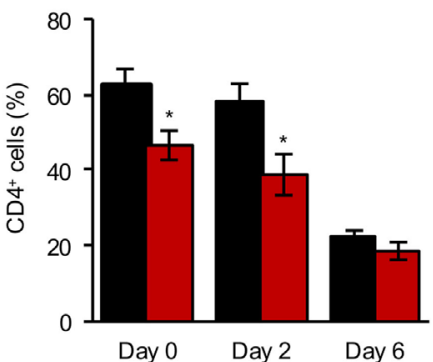

H
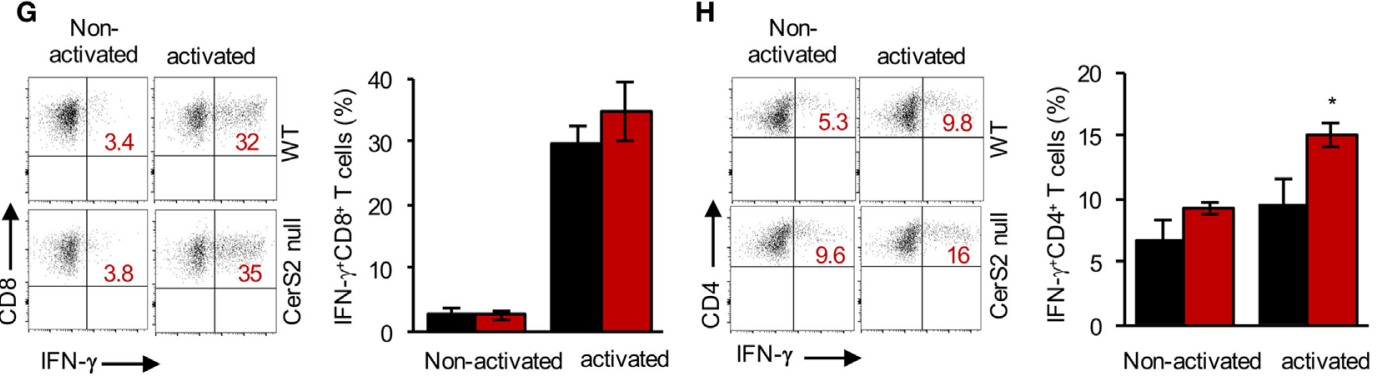

FIGURE 1 | Increased susceptibility of ceramide synthase 2 (CerS2)-null mice to LCMV infection. (A) Representative images of wild-type (WT) and CerS2-null liver stained with an anti-LCMV antibody after infection with $2 \times 10^{6}$ plaque-forming units LCMV-WE for 2 and 6 days. Scale bar, $20 \mu \mathrm{m}$. (B) Viral titers 2 and 6 days post-infection (DPI). The experiment was repeated two times with similar results. (C) IFN levels were measured in a liver homogenate (5 mg protein/ml homogenate) in the liver 2 and 6 DPI. (D) qPCR of downstream target genes of IFNR1 signaling 2 DPI in the liver of WT and CerS2-null mice. (E) Total CD8 ${ }^{+}$and (F) CD4+ (percent of total $\mathrm{CD}^{+}$) T cells in the liver of WT and CerS2-null mice 2 and 6 DPI. (G) Representative flow cytometry plots and quantitation of intracellular staining of non-activated (without peptide) and activated (LCMV-specific peptide GP33) IFN $\gamma$-producing CD8 ${ }^{+}$(percent of total CD8 ${ }^{+}$cells) and (H) non-activated and activated (LCMV-specific peptide GP64) CD4+ (percent of total CD4+) cells. Liver hematopoietic cells from LCMV-infected mice 6 DPI were isolated and restimulated in vitro with LCMV-specific peptides. $n=3$ per group. Black columns, WT; red columns, CerS2 null.

LCMV-infected CerS2 null mouse liver before and after transfer of $i$ NKT cells, with differentially expressed genes in WT mice before and after infection (Figure 2E). Differentially expressed genes that were common in both comparisons, but were not common between CerS2-null mice with and without infection, were considered to be a downstream effect of 
A

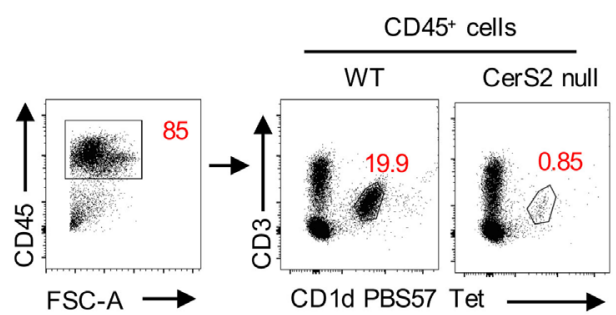

C

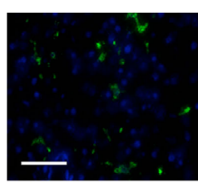

WT

+ LCMV

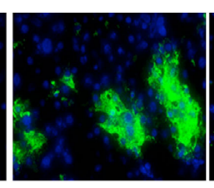

CerS2 null + LCMV

E

(71) I

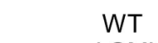

$\begin{aligned} & \text { WT } \\ + & \text { LCMV }\end{aligned}$

CerS2 null + LCMV

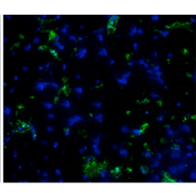

CerS2 null

+ LCMV

+ iNKT

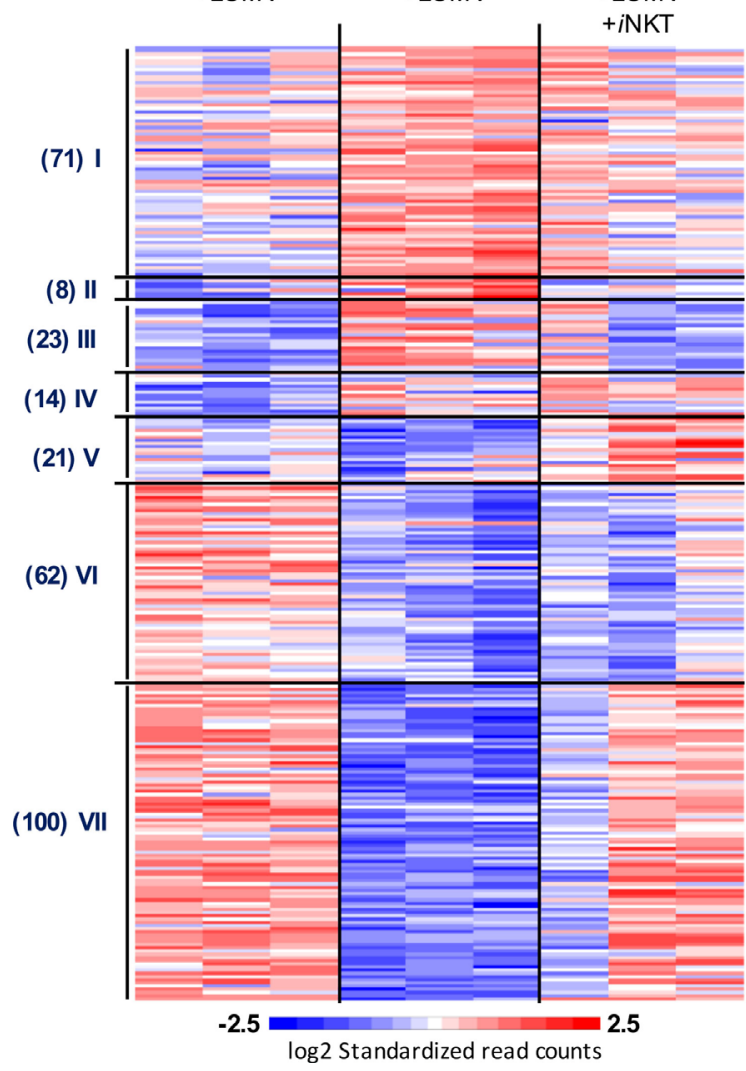

F
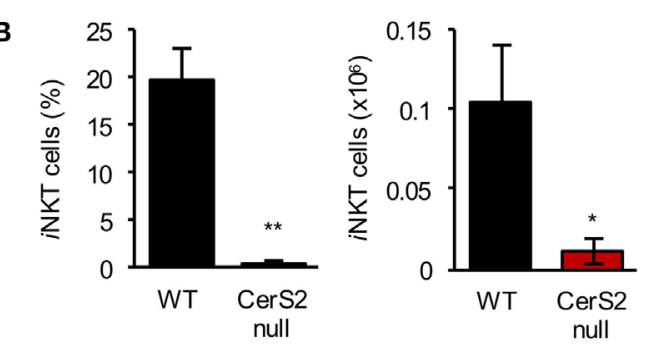

D
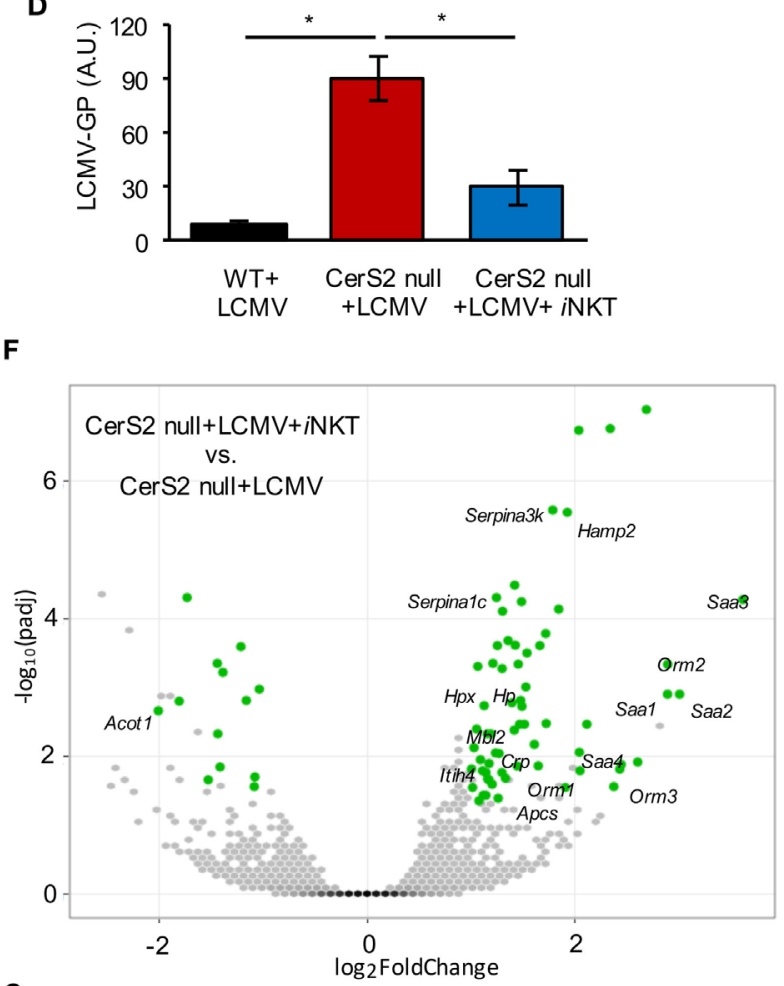

G

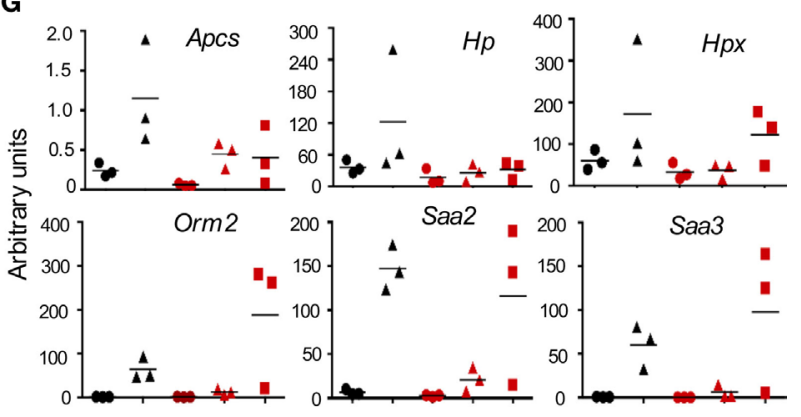

- WT $\Delta$ WT+LCMV

- CerS2 null $\triangle$ CerS2 null+LCMV a CerS2 null+LCMV+iNKT

FIGURE 2 | Reduced invariant NKT (iNKT) cells in the liver of ceramide synthase 2 (CerS2)-null mice account for their susceptibility to LCMV infection.

(A) Representative flow cytometry plots showing the percent of CD3 ${ }^{+} \mathrm{CD} 1 \mathrm{~d}-\mathrm{PBS} 57$ tetramer ${ }^{+}$iNKT cells (indicated by numbers in red) out of total hematopoietic $\left(\mathrm{CD} 45^{+}\right)$cells. (B) Percent and absolute numbers of iNKT cells $(n=4)$. (C) Representative images of viral staining in liver of wild-type (WT), CerS2 null, and CerS2-null mice after adoptive transfer of isolated WT iNKT cells 2 days post-infection. Scale bar, $20 \mu \mathrm{m}$. (D) qPCR of LCMV-glycoprotein (GP). The experiment was repeated three times with similar results. Black columns, WT; red columns, CerS2 null. (E) Heatmap of mRNA profiles of liver from LCMV-infected WT, CerS2-null mice, and CerS2-null mice after WT iNKT cell transfer $(n=3)$. Differentially expressed genes were clustered using Pearson's dissimilarity, and the number of partition clusters was set to seven. (F) Volcano plot displaying statistical significance (-log10 adjusted $p$ value) against the log2 ratio between LCMV-infected CerS2-null mice and LCMV-infected CerS2-null mice after iNKT cell transfer, based on RNA-seq data. Significantly changed genes (log2 fold change, adjusted $p$ value $<0.05, n=3$ for each group) are represented by green symbols. Genes are labeled that were significant and common between LCMV-infected CerS2-null mice/LCMV-infected CerS2-null mice after iNKT cells transfer and WT mice before and after LCMV infection but not in CerS2 null before and after LCMV infection. (G) qRT-PCR analysis of various differentially expressed genes from cluster VII. 
$i$ NKT cells (Figure 2F). Transfer of $i$ NKT cell into CerS2-null mice altered the expression of some genes similar to those of WT infected liver (Figure 2E, mainly in cluster VII). Since $i$ NKT cells contribute a small fraction of the total RNA (as only $10^{6} i \mathrm{NKT}$ cells were transferred), most of the genes whose expression was altered are hepatocyte derived (Figure 2F). Increased expression of several acute-phase reactants, such as amyloid A proteins (Saa1, Saa2, Saa3), amyloid P component serum (Apcs), haptoglobin ( $H p)$, hemopexin $(H p x)$ and orosomucoid 2 (Orm2), was observed only in CerS2-null mice after transfer of $i$ NKT cells and infection with LCMV (Figure 2F). Changes in gene expression were validated for selected acutephase genes by qRT-PCR, and compared to uninfected mice (Figure 2G). While expression of $\mathrm{Hpx}$, Orm2, Saa2, and Saa3 were increased upon transfer of WT $i$ NKT cells into LCMVinfected CerS2-null mice, Apcs, and Hp were not increased, indicating that these genes are not influenced directly by $i$ NKT cells (Figure 2F).

\section{The Development of CerS2 Null iNKT Cells Is Arrested in the Thymus}

Lower levels of $i \mathrm{NKT}$ cells were also detected in the thymus of CerS2-null mice, while levels of conventional $\mathrm{T}$ cells were unaltered (Figures 3A,B). $i$ NKT cells were arrested in their development at the immature DP stage since CerS2-null mice accumulated immature $\mathrm{CD} 24^{+} \mathrm{CD} 44^{-} i \mathrm{NKT}$ cells (stage 0) and had less mature CD24-CD44 high $i$ NKT cells (stage 2/3) (Figures 3C,D). Further analysis revealed that most of the cells which were $\mathrm{CD} 24^{-} \mathrm{CD} 44^{+}$were at stage $3\left(\mathrm{NK} 1.1^{+}\right.$cells) in both WT and CerS2-null mice (Figures 3E,F; Figure S4 in Supplementary Material). However, in CerS2-null mice, there was a small but non-significant increase in stage $2 i$ NKT cells (Figures 3E,F). The arrest of CerS2 null $i$ NKT cell maturation could reflect a cell-intrinsic defect in the survival or proliferation of $i$ KKT cells as they mature in CerS2-null mice, or alternatively could be due to extrinsic defects such as reduced surface expression of CD1d or lack of lipid self-antigens allowing thymic positive selection of $i$ NKT cells.

Unlike conventional T cells, $i$ NKT cells are selected $v i a$ the presentation of lipid self-antigen(s) by CD1d on DP thymocytes $(46,47)$. CerS2 null DP thymocytes exhibited a $34 \pm 1.5 \%$ reduction in CD1d surface expression (Figures 4A,B). Our previous studies demonstrated that surface expression of a number of receptors is reduced in CerS2-null mice $(18,25,26)$. To directly test the impact of reduced levels of CD1d on $i$ NKT cells, we generated BM culture-derived dendritic cells (BMDCs). In response to $\alpha$-GalCer, CerS2-null BMDCs, although they displayed a $48 \pm 4 \%$ reduction in surface expression of CD1d (Figures 4C,D), activated an $i$ NKT cell hybridoma cell line (DN32.D3) to a similar extent as WT controls (Figure 4E). Moreover, CD1d $\mathrm{d}^{+/-}$mice, which have a $50 \%$ reduction in surface CD1d expression on DP thymocytes, contain a normal $i \mathrm{NKT}$ cell compartment (46). We conclude that the reduced expression of CD1d in CerS2 null DP thymocytes is unlikely to account for the reduced number of $i$ NKT cells.

\section{Reduced Levels of iNKT Cells in CerS2- Null Mice Likely Results from Lack of Self-antigens}

We next generated BM chimeras by transfer of WT BM into irradiated CerS2 null hosts (WT $>\mathrm{KO})$ and vice versa $(\mathrm{KO}>\mathrm{WT})$. $\mathrm{WT}>\mathrm{KO}$ and WT $>$ WT chimeras had a similar percent of $i$ NKT cells in the thymus (Figures $\mathbf{5 A}, \mathbf{B}$ ). In contrast, levels of $i$ NKT cells in KO $>$ WT chimeras were reduced and similar to levels found in $\mathrm{KO}>\mathrm{KO}$ chimeras (Figures $\mathbf{5 A}, \mathbf{B}$ ). These results demonstrate that CerS2 expression by hematopoietic cells is required for thymic $i \mathrm{NKT}$ cell development.

Consistent with changes in the SL composition in other organs in CerS2-null mice $(16,21,23)$, levels of VLC-ceramide and VLC-GlcCer were reduced in CerS2 null thymocytes (Figure 5C). However, GalCer levels were below the limit of detection $(0.05 \mathrm{pmol} /$ mg protein) in WT and CerS2-null thymocytes.

While thymic $i$ NKT cells in WT $>$ KO chimeras were unaffected (Figures 5A,B), levels of $i$ NKT cells in the liver of WT $>$ KO chimeras were reduced to similar levels as found in $\mathrm{KO}>\mathrm{KO}$ chimeras (Figures 5D,E). Moreover, $\mathrm{KO}>\mathrm{WT}$ chimeras displayed normal $i$ NKT cell levels in the liver, similar to WT $>$ WT chimeras (Figures 5D,E), indicating that radiationresistant parenchymal cells are essential for $i$ NKT cell survival and maintenance in the liver.

Further analysis of BM chimeras using CD45.1 $1^{+} \mathrm{WT}$ donors revealed that in KO $>$ WT chimeras, $~ 90 \%$ of the $i$ NKT cells in the liver were WT-derived (Figure 5F). This is likely due to incomplete depletion of host $\mathrm{T}$ cells during irradiation $(48,49)$, which also occurs for conventional $\mathrm{T}$ cells but not for $\mathrm{B}$ cells (Figure S2A in Supplementary Material), perhaps indicating that CerS2 null $\mathrm{T}$ lymphocytes (including $i \mathrm{NKT}$ cells) have a reduced capacity to compete with residual WT cells (Figure 5F). In the thymus, although very few $\mathrm{CD} 4^{+} i \mathrm{NKT}$ cells were recovered in $\mathrm{KO}>\mathrm{WT}$ chimeras (Figure 5A), $~ 50 \%$ were KO-derived (CD45.1 cells; Figure 5F), probably due to antigen presentation by residual WT DP thymocytes, allowing limited CerS2 null $i$ NKT cell maturation. However, these cells were nearly completely absent in the liver of $\mathrm{KO}>\mathrm{WT}$ chimeras $(<10 \%$; Figure 5F). In conclusion, the chimera experiments reveal that CerS2-deficient conventional $\mathrm{T}$ and $i \mathrm{NKT}$ cells have an intrinsic defect when competing with WT cells. However, in CerS2-null mice, where no competition with WT cells occurs, this is unlikely to be the reason for reduced levels of $i$ NKT in the thymus, which are arrested at the DP stage when positive selection takes place.

\section{DISCUSSION}

In the current study we provide evidence that generation and maintenance of $i$ NKT cells depends on levels of VLC-SLs. The reversibility of the susceptibility to LCMV infection upon adoptive transfer of WT $i$ NKT cells into CerS2-null mice strongly supports this contention. These results are in agreement with reports showing that increased levels of $i$ NKT cell in the liver are protective against early stages of LCMV infection $(50,51)$, consistent with a critical role for $i$ NKT cells in the early stages of hepatic viral infection (52). The redundant role 
A
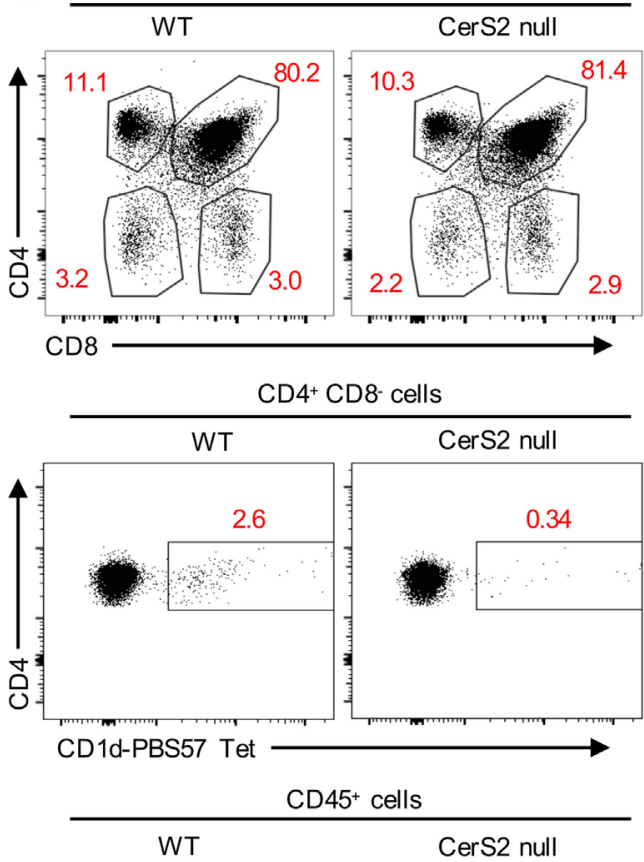

$\overbrace{0}^{4}$
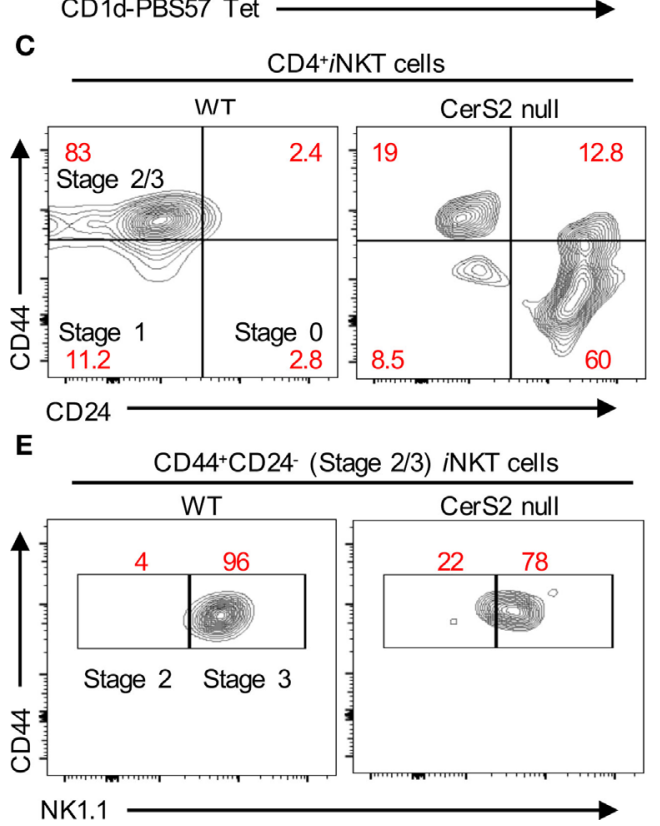
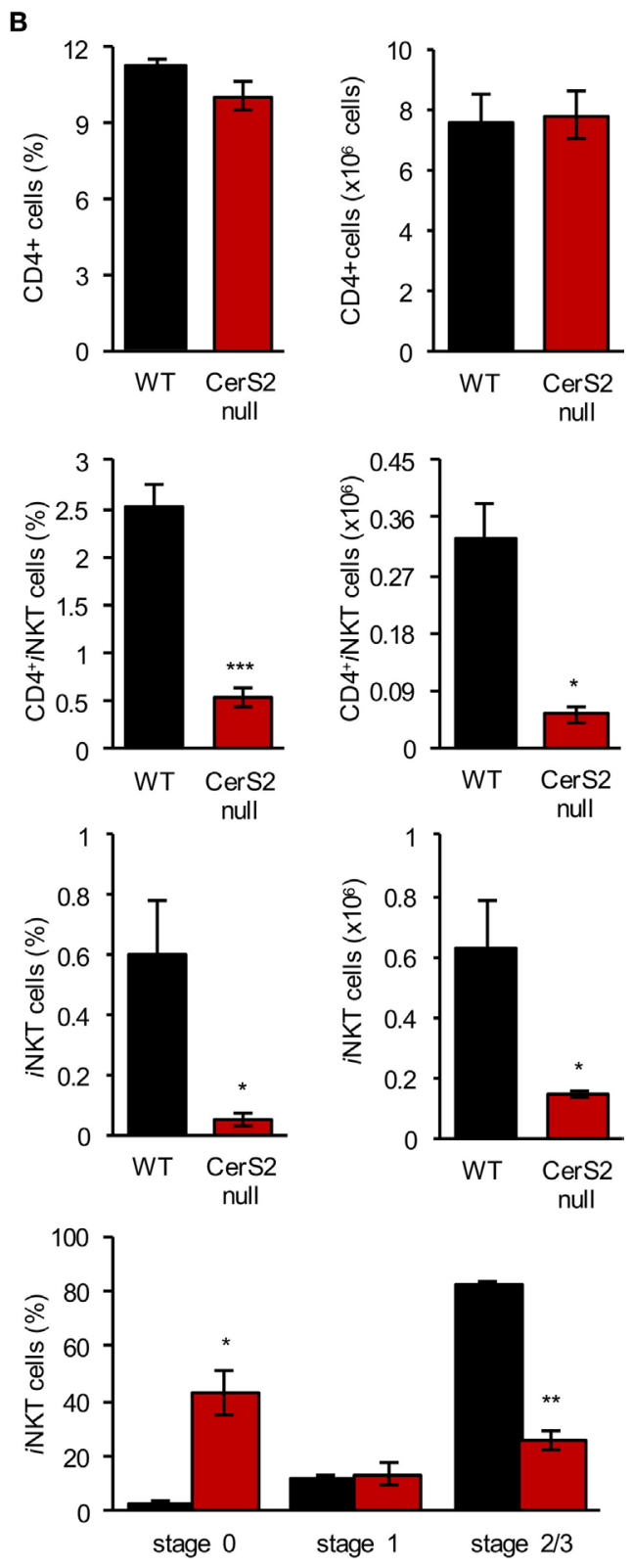

$\mathbf{F}$

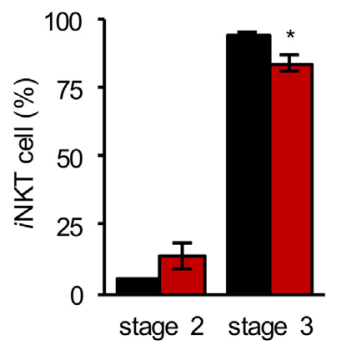

FIGURE 3 | Reduced levels of invariant NKT (INKT) cells in the thymus of ceramide synthase 2 (CerS2)-null mice is due to their impaired maturation in the thymus.

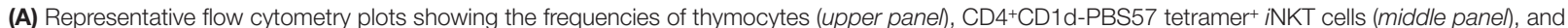
$\mathrm{CD}^{+}{ }^{+}$CD1d-PBS57 tetramer ${ }^{+}$iNKT cells (lower panel) out of total hematopoietic cells in wild-type (WT) and CerS2-null mice. (B) Average percent and absolute number of the indicated cells $(n=5)$. (C,E) Representative flow cytometry contour plots showing the percent of different developmental stages of iNKT cells in the thymus. (D,F) Average percent of iNKT cells at different developmental stages in the thymus $(n=3)$. The experiment was repeated two times with similar results. Percents are indicated in red. Black columns, WT; red columns, CerS2 null. 


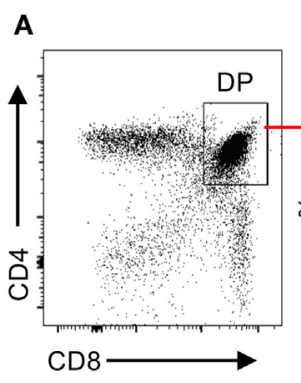

C

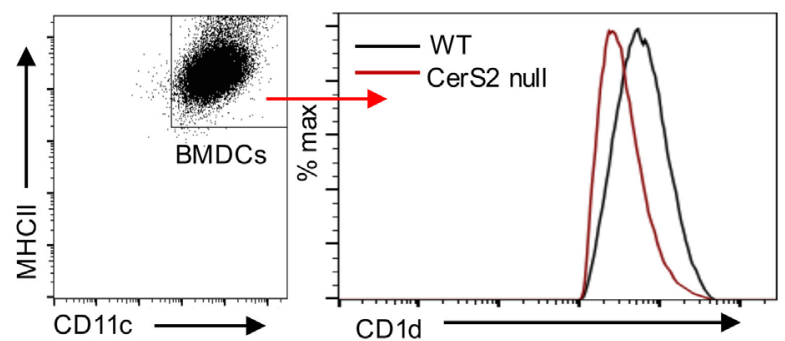

E
$\mathrm{CD}^{+}{ }^{+} \mathrm{CD} 8^{+}(\mathrm{DP})$

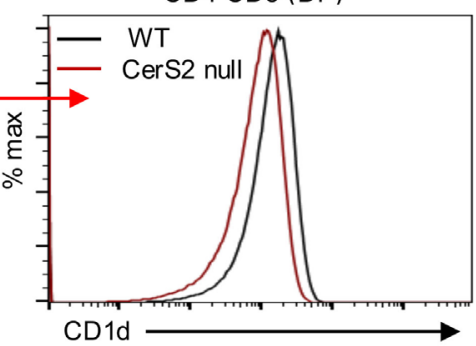

BMDCs
B

D
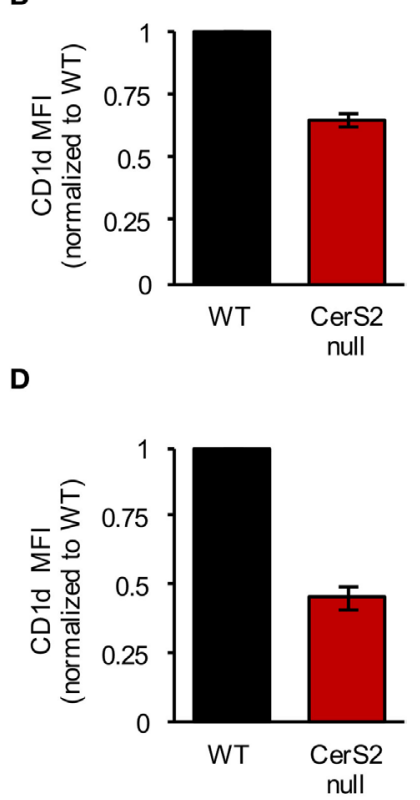

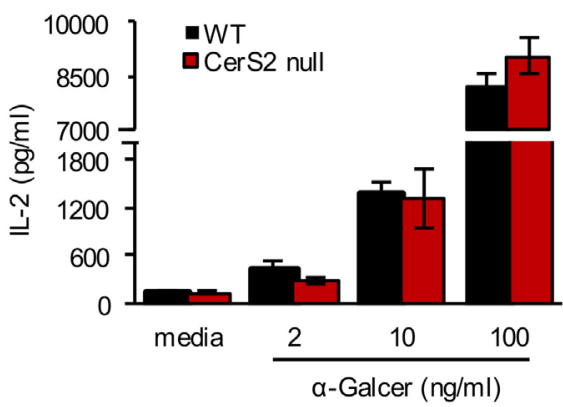

FIGURE 4 | CD1d expression in ceramide synthase 2 (CerS2)-null mice. (A) Representative flow cytometry plot of CD4+CD8+ DP thymocytes (left pane/) and histogram showing surface expression of CD1d on DP thymocytes in the thymus of wild-type (WT) and CerS2-null mice (right panel) (B) Quantitation of mean fluorescence intensity (MFI) of CD1d on DP thymocytes in WT and CerS2-null mice $(n=4)$. (C) Representative flow cytometry plot of BMDCs (left pane/) and histogram (right panel) showing CD1d surface expression on BMDCs derived from WT and CerS2-null mice. (D) Quantitation of MFI of CD1d on BMDCs derived from WT and CerS2-null mice $(n=3)$. The experiment was repeated three times with similar results. (E) Activation of DN32.D3 NKT hybridoma cells by $\alpha$-GalCer incubated with BMDCs. The experiment was performed three times in triplicate with similar results. Black columns, WT; red columns, CerS2 null.

of $i$ NKT cells in splenic viral infection $(51,53)$ explains why CerS2 null mouse spleen was not more susceptible to LCMV infection.

We demonstrate that $i \mathrm{NKT}$ cells promote the secretion of Saal and other acute-phase proteins in the early stage of viral infection in the liver. Acute-phase proteins are secreted from hepatocytes upon infection to control infection and restore homeostasis (54). Saal switches neutrophils from an anti- to a pro-inflammatory state and promotes their interaction with $i$ NKT cells (55). Saa 1 and Saa3 are increased upon HCV infection, while Acot1, which hydrolyzes long chain fatty acyl CoAs was downregulated (56), similar to our results upon $i$ NKT cell transfer into CerS2 null infected mice (Figure 2F). Together our results suggest that CerS2-null mice lacking $i \mathrm{NKT}$ cells cannot control viral propagation in part due to lack of specific acutephase proteins and possibly also due to other pathways such as those involved in lipid metabolism.
When considering the role of GSLs in the generation and activation of $i \mathrm{NKT}$ cells, three issues need to be addressed, namely, the acyl chain length of the GSL, the type of the glycosyl head group, and the anomeric configuration of the glycoside bond. For the first issue, previous studies suggested a role for the SL acyl chain length in binding to CD1d and in the affinity of this complex for the $i$ NKT TCR, with both the long chain base and the acyl chain length determining the stability of lipids bound to CD1d molecules and $i$ NKT activation $(50,57,58)$. Our study supports the idea that VLC-GSLs are major endogenous ligands necessary for $i$ NKT cell maturation in the thymus $(59,60)$ and maintenance in the liver where $i \mathrm{NKT}$ cells seek foreign lipids antigens within hepatic sinusoids. In respect to the headgroup of the glycolipid, mice deficient in $\beta$-GalCer synthase have normal $i$ NKT cell levels and their antigen-presenting cells (APC) can activate an $i \mathrm{NKT}$ hybridoma cell line, while cell lines deficient in $\beta$-GlcCer synthase cannot (61). Moreover, depletion of GlcCer-derived GSLs 
A

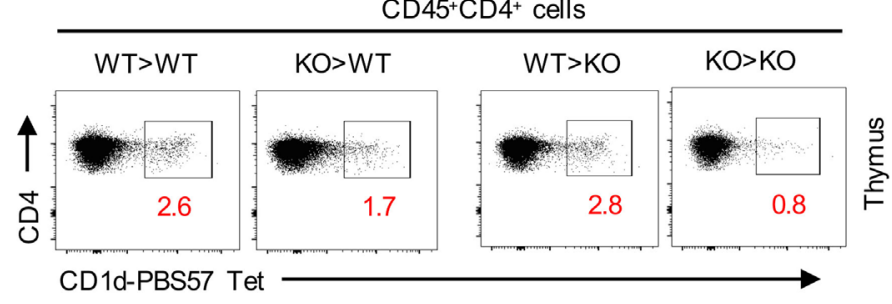

B

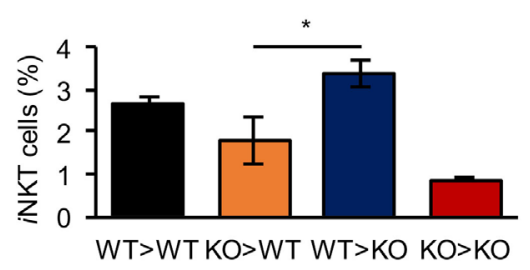

C

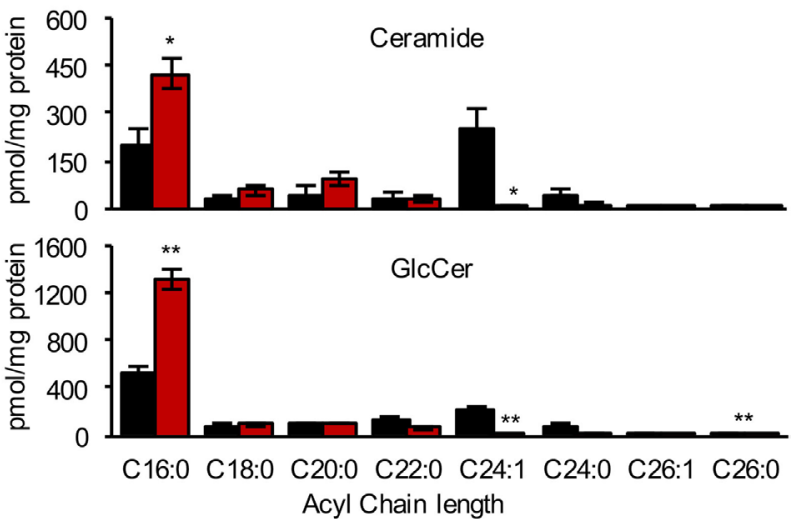

D

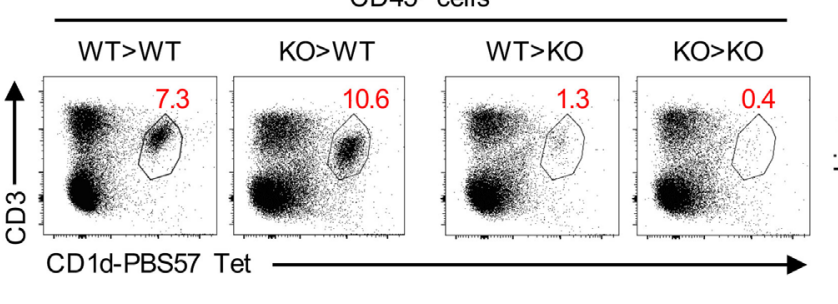

E

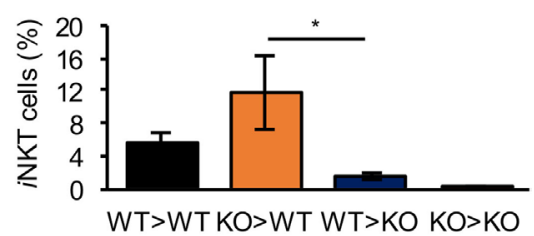

$\mathbf{F}$

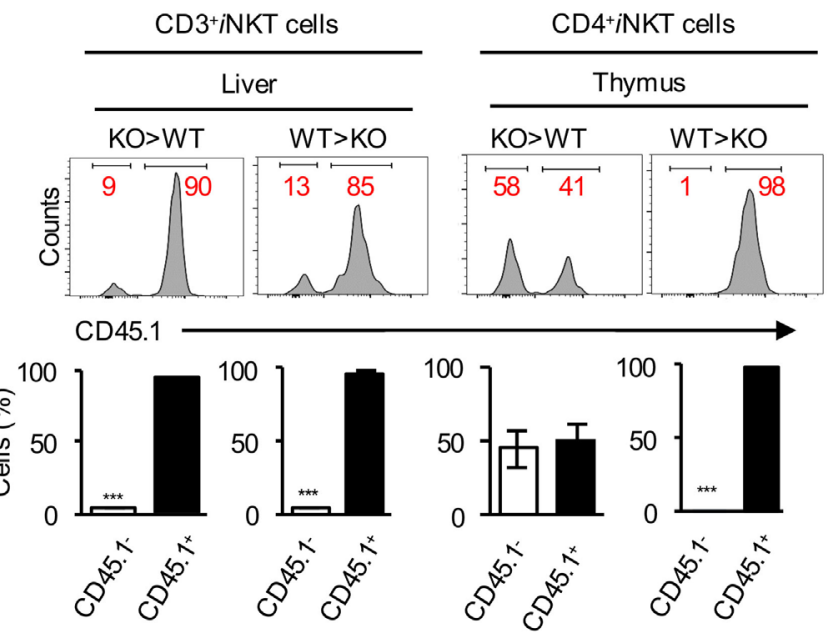

FIGURE 5 | Survival signals from non-hematopoietic cells are required for invariant NKT (NKT) cell survival in the liver. (A) Representative flow cytometry plots showing the frequency and (B) average frequency of INKT (out of total CD4+ hematopoietic cells) in the thymus of bone marrow (BM) chimeras. (C) Quantification of the acyl chain lengths of ceramide (upper pane/) and glucosylceramide (GlcCer) (lower panel) in thymocytes of wild-type (WT) (black) and ceramide synthase 2 (CerS2) null (red) mice. (D) Representative flow cytometry plots showing the frequency and (E) average frequency of CD3+ iNKT cells (out of CD45+ cells) in the liver of BM chimeras. (F) Representative flow cytometry histograms of BM chimeras, where WT cells are CD45.1+ and CerS2-null cells are CD45.1- [numbers in red indicate the percent of total $\mathrm{CD}^{+}$iNKT cells in liver and CD4+ NKT cells in thymus (upper pane/)]. Quantitation of CD45.1 staining of iNKT cells in liver and thymus of CerS2-null mice (lower panel). $n=2-4$ in each group of mice. The experiment was repeated twice with similar results. 
in DP thymocytes resulted in $\sim 50 \%$ reduction of the $i$ NKT cell population in the thymus and periphery (62). This supports the notion that C24:1-GlcCer, or more complex GSLs, are the major self-antigens required for $i \mathrm{NKT}$ cell development in the thymus and that lack of VLC-SLs in CerS2 null antigen-presenting DP thymocytes leads to reduced levels of $i$ NKT cells. Concerning the anomeric configuration, previous studies have suggested that an $\alpha$-linked monoglycosylceramide with a C24:1 acyl chain might be an endogenous ligand of $i$ NKT cells (4), although the existence of $\alpha$-GlcCer in mammals is still somewhat controversial $(5,14)$ whereas C24:1- $\beta$-GlcCer is found at high levels in mouse thymus (63). Our data showing lower levels of VLC-GlcCer, concomitant with lower levels of $i$ NKT cells, suggest that VLC-GlcCer, or complex VLC-GSLs, act as the endogenous self-antigens presented by CD1d molecules.

The precise mechanism by which $i$ NKT cell maturation is affected in the thymus of CerS2-null mice is currently unknown. However, even though a number of cell surface receptors are mislocalized in CerS2-null mice $(18,25,26)$, we can exclude the possibility that changes in cell surface expression of CD1d are responsible for the lower levels of $i$ NKT cells in CerS2-null mice. However, we cannot rule out other intrinsic defects in $i$ NKT cells. For example, the increased levels of C16-SLs in CerS2 null thymocytes (Figure 5C) might affect lysosomal loading of other self-antigens onto CD1d (64), as occurs in some mouse models of lysosomal storage diseases (59), where massive accumulation of SLs and GSLs occurs (65). However, given the relatively low level of C16-SL accumulation in CerS2 null thymocytes ( $<2$-fold; Figure 5C), we consider this unlikely. Not only are VLC-GSLs required for the maturation of $i$ NKT cells in the thymus, our data show that they are also appear to be essential for $i \mathrm{NKT}$ cell survival and maintenance in the liver. However, previous studies have shown that in the absence of CD1d, $i$ NKT cells can still proliferate in the liver although to a lower extent (66-68). Thus, it seems that survival of $i$ NKT cells in the liver is a combined effect of antigen presentation by CD1d, as well as other cofactors that may also be deficient in CerS2-null mice. However, reduced expression of known factors required for $i$ NKT cell recruitment and survival, such as CXCL16 (69), IL-15 (67), IL-7 (70), and ICOSL (71) was not observed in CerS2 null mouse liver (17). Recently, CerS2 was shown to regulate sphingosine 1-phosphate (S1P) levels and S1P-dependent egress of mature thymocytes from the thymus to the periphery (72), with increased levels of mature thymocytes found in the thymus of CerS2-null mice, which could not exit due to the lack of a S1P gradient. Our study did not show significant changes in levels of mature thymocytes in CerS2-null mice (Figure 3A), which could be due to the different genetic backgrounds of the CerS2null mice used in the two studies. Irrespective, this is unrelated to the reduced levels of $i$ NKT thymocytes in CerS2-null mice, which results from an arrest in maturation arrest at the DP stage (Figures 3C,D).

In conclusion, our data suggest that VLC-SLs (such as C24:1GSLs) are endogenous self-antigens recognized by developing $i$ NKT cells in the thymus and highlight the importance of parenchymal VLC-GSLs, which might also be required for $i$ NKT cell survival in the liver.

\section{ETHICS STATEMENT}

This study was carried out in accordance with the recommendations of international guidelines. The protocol was approved by the Institutional Animal Care and Use Committee (IACUC).

\section{AUTHOR CONTRIBUTIONS}

AS and YP-J performed and designed the experiments and wrote the manuscript. NSF performed the RNA seq and EF did the bioinformatics analysis. PS analyzed viral titers. AM and SK carried out ESI-MS/MS analyses of SLs. YJ performed in vitro iNKT cell activation experiments, and FT and CP helped write the manuscript. KL provided the LCMV-WE virus, infected mice, and helped write the manuscript. AHF supervised and funded the studies and wrote the manuscript.

\section{ACKNOWLEDGMENTS}

The authors thank Dr. Tomer Meir Salame from the FACS unit in the Weizmann Institute of Science for his excellent technical support. The authors also thank the NIH Tetramer Core Facility, Emory University, Georgia, USA for providing CD1d-PBS57 loaded tetramers. This study was supported by the Atheroflux consortium (EU grant FP7-602222-2), the Israel Science Foundation (grant 1728/15), and the National Institutes of Health (grant GM076217). AS was supported by the Planning and Budgeting Committee program for outstanding post-doctoral researchers. AHF is the Joseph Meyerhoff Professor of Biochemistry at the Weizmann Institute of Science.

\section{SUPPLEMENTARY MATERIAL}

The Supplementary Material for this article can be found online at http://www.frontiersin.org/article/10.3389/fimmu.2017.01386/ full\#supplementary-material.

FIGURE S1 | Analysis of hepatocytes and immune cells in ceramide synthase 2 (CerS2)-null mice after LCMV infection. (A) Representative images of LCMV-infected hepatocytes (MOI 1:100) from wild-type (WT) and CerS2-null mice 12, 16, 20, 24, and $48 \mathrm{~h}$ post-infection. (B) Frequencies of CD 45+CD11b-CD11 c+PDCA1+ pDCs, (C) CD45+CD11 b+Ly6C+ monocytes, (D) $\mathrm{CD} 45^{+} \mathrm{CD} 11 \mathrm{~b} \mathrm{~b}^{+} \mathrm{Ly} 6 \mathrm{G}^{+}$neutrophils in the liver of WT and CerS2-null mice 2 and 6 DPI. $n=2-3$ in each group. Experiments were repeated at least twice with similar results.

FIGURE S2 | CD45.1 staining in liver and thymus of bone marrow (BM) chimeras. (A) Representative flow cytometry histograms (upper panel) and average frequencies (lower panel) showing CD45.1- and CD45.1+ staining (numbers in red are percent of total cells) in liver and (B) thymus of BM chimeras. Wild-type (WT) are CD45.1+ and ceramide synthase 2 (CerS2) null are CD45.1-. $n=2-4$ in each group. Each experiment was repeated twice with similar results.

FIGURE S3 | The effect of LCMV infection after transfer of wild-type (WT) iNKT cell-enriched fractions versus transfer of the iNKT-depleted fraction. (A) Representative flow cytometry plots showing the purity of the bound fraction enriched for iNKT cells and (B) the unbound fraction rich in conventional T cells. Red numbers represent percent of gated cells. (C) Representative images of LCMV staining in liver sections of ceramide synthase 2 (CerS2)-null mice 2 days 
post-infection after transfer of the bound $(n=3)$ and $(\mathbf{D})$ unbound $(n=2)$ cell fractions.

FIGURE S4 | NK1.1 staining on iNKT cells from C57BL6 and F1 mice. (A) Representative flow cytometry contour plots showing gating strategy for NK1.1 positive and negative iNKT cells in C57BL/6, and F1 (C57BL/6 × 129S4/ Jae) wild-type (WT) mice. Unstained control staining included all reagents (including SA-APC) used for all the other staining except for bio-anti-NK1.1

\section{REFERENCES}

1. Godfrey DI, Stankovic S, Baxter AG. Raising the NKT cell family. Nat Immunol (2010) 11:197-206. doi:10.1038/ni.1841

2. Matsuda JL, Naidenko OV, Gapin L, Nakayama T, Taniguchi M, Wang CR, et al. Tracking the response of natural killer T cells to a glycolipid antigen using CD1d tetramers. J Exp Med (2000) 192:741-54. doi:10.1084/ jem.192.5.741

3. Kobayashi E, Motoki K, Uchida T, Fukushima H, Koezuka Y. KRN7000, a novel immunomodulator, and its antitumor activities. Oncol Res (1995) 7:529-34.

4. Kain L, Webb B, Anderson BL, Deng S, Holt M, Costanzo A, et al. The identification of the endogenous ligands of natural killer $\mathrm{T}$ cells reveals the presence of mammalian $\alpha$-linked glycosylceramides. Immunity (2014) 41:543-54. doi:10.1016/j.immuni.2014.08.017

5. Gerichten von J, Schlosser K, Lamprecht D, Morace I, Eckhardt M, Wachten D, et al. Diastereomer-specific quantification of bioactive hexosylceramides from bacteria and mammals. J Lipid Res (2017) 58:1247-58. doi:10.1194/jlr.D076190

6. Hannun YA, Obeid LM. Many ceramides. J Biol Chem (2011) 286:27855-62. doi:10.1074/jbc.R111.254359

7. Levy M, Futerman AH. Mammalian ceramide synthases. IUBMB Life (2010) 62:347-56. doi:10.1002/iub.319

8. Park J-W, Park W-J, Futerman AH. Ceramide synthases as potential targets for therapeutic intervention in human diseases. Biochim Biophys Acta (2014) 1841:671-81. doi:10.1016/j.bbalip.2013.08.019

9. Halasiddappa LM, Koefeler H, Futerman AH, Hermetter A. Oxidized phospholipids induce ceramide accumulation in RAW 264.7 macrophages: role of ceramide synthases. PLoS One (2013) 8:e70002. doi:10.1371/journal. pone.0070002

10. Holliday MW Jr, Cox SB, Kang MH, Maurer BJ. C22: 0-and C24: 0 -dihydroceramides confer mixed cytotoxicity in T-cell acute lymphoblastic leukemia cell lines. PLoS One (2013) 8(9):e74768. doi:10.1371/journal. pone. 0074768

11. Iwabuchi K, Prinetti A, Sonnino S, Mauri L, Kobayashi T, Ishii K, et al. Involvement of very long fatty acid-containing lactosylceramide in lactosylceramide-mediated superoxide generation and migration in neutrophils. Glycoconj J (2008) 25:357-74. doi:10.1007/s10719-007-9084-6

12. Kroesen B-J, Jacobs S, Pettus BJ, Sietsma H, Kok JW, Hannun YA, et al. BcRinduced apoptosis involves differential regulation of C16 and C24-ceramide formation and sphingolipid-dependent activation of the proteasome. J Biol Chem (2003) 278:14723-31. doi:10.1074/jbc.M210756200

13. Seumois G, Fillet M, Gillet L. De novo C16- and C24-ceramide generation contributes to spontaneous neutrophil apoptosis. JLeukoc Biol (2007) 81:1477-86. doi:10.1189/jlb.0806529

14. Brennan PJ, Tatituri RVV, Heiss C, Watts GFM, Hsu F-F, Veerapen N, et al. Activation of iNKT cells by a distinct constituent of the endogenous glucosylceramide fraction. Proc Natl Acad Sci U S A (2014) 111:13433-8. doi:10.1073/pnas.1415357111

15. Lee YJ, Holzapfel KL, Zhu J, Jameson SC. Steady-state production of IL-4 modulates immunity in mouse strains and is determined by lineage diversity of iNKT cells. Nature (2013) 14:1146-54. doi:10.1038/ni.2731

16. Pewzner-Jung Y, Park H, Laviad EL, Silva LC, Lahiri S, Stiban J, et al. A critical role for ceramide synthase 2 in liver homeostasis: I. alterations in lipid metabolic pathways. J Biol Chem (2010) 285:10902-10. doi:10.1074/ jbc.M109.077594

17. Pewzner-Jung Y, Brenner O, Braun S, Laviad EL, Ben-Dor S, Feldmesser E, et al. A critical role for ceramide synthase 2 in liver homeostasis: II.
(B) Intensity of NK1.1 expression in iNKT cells in C57 BL/6, and F1 WT mice and WT unstained negative control $(n=3)$.

DATA SHEET S1 | Raw RNAseq data and analysis of differentially expressed genes in livers isolated from wild-type (WT) and ceramide synthase 2 (CerS2)null mice with and without LCMV infection, and LCMV-infected CerS2-null mice after transfer of WT iNKT cells. The data have been uploaded to Gene Expression Omnibus (GEO), accession number GSE104205.

insights into molecular changes leading to hepatopathy. J Biol Chem (2010) 285:10911-23. doi:10.1074/jbc.M109.077610

18. Park J-W, Park W-J, Kuperman Y, Boura-Halfon S, Pewzner-Jung Y, Futerman AH. Ablation of very long acyl chain sphingolipids causes hepatic insulin resistance in mice due to altered detergent-resistant membranes. Hepatology (2012) 57:525-32. doi:10.1002/hep.26015

19. Zigdon H, Kogot-Levin A, Park J-W, Goldschmidt R, Kelly S, Merrill AH, et al. Ablation of ceramide synthase 2 causes chronic oxidative stress due to disruption of the mitochondrial respiratory chain. J Biol Chem (2013) 288:4947-56. doi:10.1074/jbc.M112.402719

20. Ben-David O, Pewzner-Jung Y, Brenner O, Laviad EL, Kogot-Levin A, Weissberg I, et al. Encephalopathy caused by ablation of very long acyl chain ceramide synthesis may be largely due to reduced galactosylceramide levels. J Biol Chem (2011) 286:30022-33. doi:10.1074/jbc.M111.261206

21. Petrache I, Kamocki K, Poirier C, Pewzner-Jung Y, Laviad EL, Schweitzer KS, et al. Ceramide synthases expression and role of ceramide synthase- 2 in the lung: insight from human lung cells and mouse models. PLoS One (2013) 8:e62968. doi:10.1371/journal.pone.0062968

22. Pewzner-Jung Y, Tavakoli Tabazavareh S, Grassme H, Becker KA, Japtok L, Steinmann J, et al. Sphingoid long chain bases prevent lung infection by Pseudomonas aeruginosa. EMBO Mol Med (2014) 6:1205-14. doi:10.15252/emmm.201404075

23. Park W-J, Brenner O, Kogot-Levin A, Saada A, Merrill AH, Pewzner-Jung Y, et al. Development of pheochromocytoma in ceramide synthase 2 null mice. Endocr Relat Cancer (2015) 22:623-32. doi:10.1530/ERC15-0058

24. Ali M, Fritsch J, Zigdon H, Pewzner-Jung Y, Schütze S, Futerman AH. Altering the sphingolipid acyl chain composition prevents LPS/GLN-mediated hepatic failure in mice by disrupting TNFR1 internalization. Cell Death Dis (2013) 4:e929. doi:10.1038/cddis.2013.451

25. Park W-J, Park J-W, Erez-Roman R, Kogot-Levin A, Bame JR, Tirosh B, et al. Protection of a ceramide synthase 2 null mouse from drug-induced liver injury: role of gap junction dysfunction and connexin 32 mislocalization. J Biol Chem (2013) 288:30904-16. doi:10.1074/jbc.M112.448852

26. Park W-J, Park J-W, Merrill AH, Storch J, Pewzner-Jung Y, Futerman AH. Hepatic fatty acid uptake is regulated by the sphingolipid acyl chain length. Biochim Biophys Acta (2014) 1841:1754-66. doi:10.1016/j.bbalip. 2014.09.009

27. Silva LC, Ben-David O, Pewzner-Jung Y, Laviad EL, Stiban J, Bandyopadhyay $S$, et al. Ablation of ceramide synthase 2 strongly affects biophysical properties of membranes. JLipid Res (2012) 53:430-6. doi:10.1194/jlr.M022715

28. Sprent J, Surh CD. Normal T cell homeostasis: the conversion of naive cells into memory-phenotype cells. Nat Immunol (2011) 12:478-84. doi:10.1038/ ni. 2018

29. Monroe JG. ITAM-mediated tonic signalling through pre-BCR and BCR complexes. Nat Rev Immunol (2006) 6:283-94. doi:10.1038/nri1808

30. Macho-Fernandez E, Cruz LJ, Ghinnagow R, Fontaine J, Bialecki E, Frisch B, et al. Targeted delivery of $\alpha$-galactosylceramide to CD $8 \alpha+$ dendritic cells optimizes type I NKT cell-based antitumor responses. J Immunol (2014) 193:961-9. doi:10.4049/jimmunol.1303029

31. Khairnar V, Duhan V, Maney SK, Honke N, Shaabani N, Pandyra AA, et al. CEACAM1 induces B-cell survival and is essential for protective antiviral antibody production. Nat Commun (2015) 6:6217. doi:10.1038/ ncomms 7217

32. Xu HC, Grusdat M, Pandyra AA, Polz R, Huang J, Sharma P, et al. Type I interferon protects antiviral CD8 $+\mathrm{T}$ cells from NK cell cytotoxicity. Immunity (2014) 40:949-60. doi:10.1016/j.immuni.2014.05.004 
33. Jaitin DA, Kenigsberg E, Keren-Shaul H, Elefant N, Paul F, Zaretsky I, et al. Massively parallel single-cell RNA-seq for marker-free decomposition of tissues into cell types. Science (2014) 343:776-9. doi:10.1126/science.1247651

34. Martin M. Cutadapt removes adapter sequences from high-throughput sequencing reads. EMBnet J (2011) 17:10-2. doi:10.14806/ej.17.1.200

35. Dobin A, Davis CA, Schlesinger F, Drenkow J, Zaleski C, Jha S, et al. STAR: ultrafast universal RNA-seq aligner. Bioinformatics (2013) 29:15-21. doi:10.1093/bioinformatics/bts635

36. Anders S, Pyl PT, Huber W. HTSeq-a Python framework to work with high-throughput sequencing data. Bioinformatics (2015) 31:166-9. doi:10.1093/bioinformatics/btu638

37. Ali M, Saroha A, Pewzner-Jung Y, Futerman AH. LPS-mediated septic shock is augmented in ceramide synthase 2 null mice due to elevated activity of TNFo-converting enzyme. FEBS Lett (2015) 589:2213-7. doi:10.1016/j. febslet.2015.06.045

38. Zal T, Volkmann A, Stockinger B. Mechanisms of tolerance induction in major histocompatibility complex class II-restricted T cells specific for a blood-borne self-antigen. J Exp Med (1994) 180:2089-99. doi:10.1084/jem.180.6.2089

39. Shaner RL, Allegood JC, Park H, Wang E, Kelly S, Haynes CA, et al. Quantitative analysis of sphingolipids for lipidomics using triple quadrupole and quadrupole linear ion trap mass spectrometers. JLipid Res (2009) 50:1692-707. doi:10.1194/jlr.D800051-JLR200

40. Zinkernagel RM, Haenseler E, Leist T, Cerny A, Hengartner H, Althage A. $\mathrm{T}$ cell-mediated hepatitis in mice infected with lymphocytic choriomeningitis virus. Liver cell destruction by H-2 class I-restricted virus-specific cytotoxic T cells as a physiological correlate of the 51Cr-release assay? J Exp Med (1986) 164:1075-92. doi:10.1084/jem.164.4.1075

41. Teijaro JR. Type I interferons in viral control and immune regulation. Curr Opin Virol (2016) 16:31-40. doi:10.1016/j.coviro.2016.01.001

42. Fitzgerald-Bocarsly P. Natural interferon-alpha producing cells: the plasmacytoid dendritic cells. Biotechniques (2002) 22:24-9.

43. Paget $\mathrm{C}$, Trottein F. Role of type 1 natural killer $\mathrm{T}$ cells in pulmonary immunity. Mucosal Immunol (2013) 6:1054-67. doi:10.1038/mi.2013.59

44. Tessmer MS, Fatima A, Paget C, Trottein F, Brossay L. NKT cell immune responses to viral infection. Expert Opin Ther Targets (2009) 13:153-62. doi: $10.1517 / 14712590802653601$

45. Juno JA, Keynan Y, Fowke KR. Invariant NKT cells: regulation and function during viral infection. PLoS Pathog (2012) 8:e1002838. doi:10.1371/journal. ppat. 1002838

46. Sillé FCM, Boxem M, Sprengers D, Veerapen N, Besra G, Boes M. Distinct requirements for $\mathrm{CD} 1 \mathrm{~d}$ intracellular transport for development of $\mathrm{V}$ (alpha) 14 iNKT cells. J Immunol (2009) 183:1780-8. doi:10.4049/jimmunol.0901354

47. Egawa T, Eberl G, Taniuchi I, Benlagha K. Genetic evidence supporting selection of the Vo14i NKT cell lineage from double-positive thymocyte precursors. Immunity (2005) 22:705-16. doi:10.1016/j.immuni.2005.03.011

48. Schwartz E, Lapidot T, Gozes D, Singer TS, Reisner Y. Abrogation of bone marrow allograft resistance in mice by increased total body irradiation correlates with eradication of host clonable $\mathrm{T}$ cells and alloreactive cytotoxic precursors. J Immunol (1987) 138:460-5.

49. Reisner Y, Ben-Bassat I, Douer D, Kaploon A, Schwartz E, Ramot B. Demonstration of clonable alloreactive host $\mathrm{T}$ cells in a primate model for bone marrow transplantation. Proc Natl Acad Sci U S A (1986) 83:4012-5. doi:10.1073/pnas.83.11.4012

50. McCarthy C, Shepherd D, Fleire S, Stronge VS, Koch M, Illarionov PA, et al. The length of lipids bound to human CD1d molecules modulates the affinity of NKT cell TCR and the threshold of NKT cell activation. J Exp Med (2007) 204:1131-44. doi:10.1084/jem.20062342

51. Diana J, Griseri T, Lagaye S, Beaudoin L, Autrusseau E, Gautron A-S, et al. NKT cell-plasmacytoid dendritic cell cooperation via OX40 controls viral infection in a tissue-specific manner. Immunity (2009) 30:289-99. doi:10.1016/j.immuni.2008.12.017

52. Hobbs JA, Cho S, Roberts TJ, Sriram V, Zhang J, Xu M, et al. Selective loss of natural killer $\mathrm{T}$ cells by apoptosis following infection with lymphocytic choriomeningitis virus. J Virol (2001) 75:10746-54. doi:10.1128/JVI.75.22. 10746-10754.2001

53. Spence PM, Sriram V, Van Kaer L, Hobbs JA, Brutkiewicz RR. Generation of cellular immunity to lymphocytic choriomeningitis virus is independent of CD1d1 expression. Immunology (2001) 104:168-74. doi:10.1046/j.13652567.2001.01302.x
54. Gabay C, Kushner I. Acute-phase proteins and other systemic responses to inflammation. $N$ Engl J Med (1999) 340:448-54. doi:10.1056/ NEJM199902113400607

55. De Santo C, Arscott R, Booth S, Karydis I, Jones M, Asher R, et al. Invariant NKT cells modulate the suppressive activity of IL-10-secreting neutrophils differentiated with serum amyloid A. Nat Immunol (2010) 11:1039-46. doi:10.1038/ni.1942

56. Chang M-L, Yeh C-T, Chen J-C, Huang C-C, Lin S-M, Sheen I-S, et al. Altered expression patterns of lipid metabolism genes in an animal model of HCV core-related, nonobese, modest hepatic steatosis. BMC Genomics (2008) 9:109. doi:10.1186/1471-2164-9-109

57. Wun KS, Cameron G, Patel O, Pang SS, Pellicci DG, Sullivan LC, et al. A molecular basis for the exquisite CD1d-restricted antigen specificity and functional responses of natural killer T cells. Immunity (2011) 34:327-39. doi:10.1016/j.immuni.2011.02.001

58. Parekh VV, Singh AK, Wilson MT, Olivares-Villagomez D, Bezbradica JS, Inazawa $\mathrm{H}$, et al. Quantitative and qualitative differences in the in vivo response of NKT cells to distinct alpha- and beta-anomeric glycolipids. J Immunol (2004) 173:3693-706. doi:10.4049/jimmunol.173.6.3693

59. Gadola SD, Silk JD, Jeans A, Illarionov PA, Salio M, Besra GS, et al. Impaired selection of invariant natural killer $\mathrm{T}$ cells in diverse mouse models of glycosphingolipid lysosomal storage diseases. J Exp Med (2006) 203:2293-303. doi:10.1084/jem.20060921

60. Porubsky S, Speak AO, Salio M, Jennemann R, Bonrouhi M, Zafarulla R, et al. Globosides but not isoglobosides can impact the development of invariant NKT cells and their interaction with dendritic cells. J Immunol (2012) 189:3007-17. doi:10.4049/jimmunol.1201483

61. Stanic AK, De Silva AD, Park J-J, Sriram V, Ichikawa S, Hirabyashi Y, et al. Defective presentation of the CD1d1-restricted natural Va14Ja18 NKT lymphocyte antigen caused by beta-D-glucosylceramide synthase deficiency. Proc Natl Acad Sci U S A (2003) 100:1849-54. doi:10.1073/pnas. 0430327100

62. Popovic ZV, Rabionet M, Jennemann R, Krunic D, Sandhoff R, Gröne H-J, et al. Glucosylceramide synthase is involved in development of invariant natural killer T cells. Front Immunol (2017) 8:848. doi:10.3389/ fimmu.2017.00848

63. Brennan PJ, Tatituri RVV, Brigl M, Kim EY, Tuli A, Sanderson JP, et al. Invariant natural killer $\mathrm{T}$ cells recognize lipid self antigen induced by microbial danger signals. Nat Immunol (2011) 12:1202-11. doi:10.1038/ ni. 2143

64. Gumperz JE. The ins and outs of CD1 molecules: bringing lipids under immunological surveillance. Traffic (2006) 7:2-13. doi:10.1111/j.1600-0854. 2005.00364.x

65. Vruchte te D, Jeans A, Platt FM, Sillence DJ. Glycosphingolipid storage leads to the enhanced degradation of the B cell receptor in Sandhoff disease mice. J Inherit Metab Dis (2010) 33:261-70. doi:10.1007/s10545-0109109-3

66. McNab FW, Berzins SP, Pellicci DG, Kyparissoudis K, Field K, Smyth MJ, et al. The influence of CD1d in postselection NKT cell maturation and homeostasis. J Immunol (2005) 175:3762-8. doi:10.4049/jimmunol.175.6.3762

67. Matsuda JL, Gapin L, Sidobre S, Kieper WC, Tan JT, Ceredig R, et al. Homeostasis of V alpha 14i NKT cells. Nat Immunol (2002) 3:966-74. doi:10.1038/ni837

68. Wei DG, Lee H, Park S-H, Beaudoin L, Teyton L, Lehuen A, et al. Expansion and long-range differentiation of the NKT cell lineage in mice expressing CD1d exclusively on cortical thymocytes. J Exp Med (2005) 202:239-48. doi:10.1084/jem.20050413

69. Geissmann F, Cameron TO, Sidobre S, Manlongat N, Kronenberg M, Briskin MJ, et al. Intravascular immune surveillance by CXCR6 + NKT cells patrolling liver sinusoids. PLoS Biol (2005) 3:e113. doi:10.1371/journal.pbio. 0030113

70. Liang B, Hara T, Wagatsuma K, Zhang J, Maki K, Miyachi H, et al. Role of hepatocyte-derived IL-7 in maintenance of intrahepatic NKT cells and T cells and development of B cells in fetal liver. JImmunol (2012) 189:4444-50. doi:10.4049/jimmunol.1201181

71. Akbari O, Stock P, Meyer EH, Freeman GJ, Sharpe AH, Umetsu DT, et al. ICOS/ICOSL interaction is required for CD4 + invariant NKT cell function and homeostatic survival. JImmunol (2008) 180:5448-56. doi:10.4049/ jimmunol.180.8.5448 
72. Rieck M, Kremser C, Jobin K, Mettke E, Kurts C, Gräler M, et al. Ceramide synthase 2 facilitates S1P-dependent egress of thymocytes into the circulation in mice. Eur J Immunol (2017) 47(4):677-84. doi:10.1002/eji. 201646623

Conflict of Interest Statement: The authors declare that the research was conducted in the absence of any commercial or financial relationships that could be construed as a potential conflict of interest.
Copyright (c) 2017 Saroha, Pewzner-Jung, Ferreira, Sharma, Jouan, Kelly, Feldmesser, Merrill, Trottein, Paget, Lang and Futerman. This is an open-access article distributed under the terms of the Creative Commons Attribution License (CC BY). The use, distribution or reproduction in other forums is permitted, provided the original author(s) or licensor are credited and that the original publication in this journal is cited, in accordance with accepted academic practice. No use, distribution or reproduction is permitted which does not comply with these terms. 